\title{
ENERGY EFFICIENCY MODERNIZATIONS AT THE INDUSTRIAL PLANT: A CASE STUDY
}

\begin{abstract}
In the present era of continually increasing energy demand, Europe faces many challenges, such as high and unstable energy prices, growing global energy demand, increasing threat of climate change, sluggish progress within energy efficiency and issues related to increasing demand for the use of renewable energy sources. It is desirable to seek opportunities to use energy consumed most reasonably, thus ensuring continuous improvement of energy efficiency in the industry. The scope of the research includes reviewing studies in this matter and analysing the most beneficial solutions for the plant. The work aims to assess possible undertakings to modernise the energy management of an industrial plant on the example of Bulten Poland S.A. rationally and profitably for the plant. The work contains an analysis of the profitability of the potentially most beneficial solutions in terms of improving the energy efficiency of the plant. Mentioned in the article solutions, aiming increasing energy efficiency, helped become the plant independent within heating up facilities. Total heat recovery potential in amount of 18965 GJ is motivation for further activities. This is a great opportunity to reduce significantly carbon footprint (replacing lightening into LED technology reduced $\mathrm{CO}_{2}$ by $206.3 \mathrm{Mg}$ /year) and be more competitive on the market by reducing costs of product.
\end{abstract}

Keywords: energy efficiency, heat recovery, waste heat, cogeneration, compressed air system

\section{Introduction}

The EU has set itself targets related to energy and climate, which should be achieved by 2020, 2030 and 2050. Among goals to be completed by 2020 are the reduction of greenhouse gas emissions by at least $20 \%$ compared to 1990 levels, the share of energy from renewable sources in total energy consumption in amount of $20 \%$ and improvement of energy efficiency by $20 \%$ [1]. It has been estimated that by 2020, energy efficiency will increase by $18-19 \%$. It is just below the target level of $20 \%$, but it can be accomplished if European Countries effectively will motivate the industry to invest in promoting energy efficiency.

According to the decisions made in the framework of the Energy Union of 2015, we can list five most important nowadays areas of EU energy policy which are: ensuring the functioning of the internal energy market and guaranteeing interconnection; ensuring security of energy supply in the Union; promoting energy efficiency and energy saving; promoting the development of new and renewable forms of energy in order to better adapt climate change objectives to the latest market structure and better integrate them with this

\footnotetext{
${ }^{1}$ Bulten Poland S.A., ul. Bukietowa 60, 43-300 Bielsko-Biala, Poland, email: mariusz.broniszewski@bulten.com

${ }^{2}$ Department of Thermal Technology, Silesian University of Technology, ul. S. Konarskiego 22, 44-100 Gliwice, Poland, email: sebastian.werle@polsl.pl

*Corresponding author: mariusz.broniszewski@bulten.com
} 
market, as well as promoting researches, innovations and competitiveness [2]. For this reason, it is desirable to seek opportunities to use energy consumed most rationally, thus ensuring continuous improvement of energy efficiency in the industry area.

\section{Global industry consumption of energy}

Energy is an essential factor when we speak about the development of global markets and national economies. Total global energy consumption has never been limited within energy for production and other requirements, so it is needed to increase energy efficiency rather than limit energy for manufacturing goods [3]. The industry is responsible for about a third of the world's total energy usage and $36 \%$ of $\mathrm{CO}_{2}$ emissions [4]. It was reported by IEA (International Energy Agency) that, compare the level of energy usage in 1971, industrial energy consumption had increased by $61 \%$ by 2004 , caused by the successive increasing energy demand of developing countries and it will be growing continuously in the future. According to EIA projects, the growth in energy consumption is estimated at $28 \%$ by 2040 [5].

Utilizing renewable energy sources and recovering waste heat instead of consuming fossil fuels are efficient solutions and relieve the environmental harms and energy crisis, contributing to social growth and sustainable development among industry companies. However, waste heat recovery is not just a source of useful energy, but also a great way to reuse waste energy to decrease gas emissions and limiting the adverse effects of global warming.

\section{Selected heat recovery methods in industrial area}

\section{Heat recovery using heat pump}

Heat pumps utilize natural energy resources accumulated in atmospheric air, ground, surface, or underground water. It transfers low-temperature ground heat into high-temperature heat, simultaneously consuming high-quality energy as a driving force [3]. These devices take thermal energy from the source and transfer it to the building. The soil and surface waters contain considerable amounts of energy. With the help of heat pumps, at a depth of $1.5 \mathrm{~m}$, we can draw the energy that will satisfy our daily heating needs. The sun provides exactly 5,000 times more energy than the world needs annually. Depending on the season and the depth of the ground temperature, they may vary between 4 and $8{ }^{\circ} \mathrm{C}$. At depths above $15 \mathrm{~m}$, the thermal movement of the ground depends on the season, and the temperature is constant between 8 and $10{ }^{\circ} \mathrm{C}$. At deeper depths, the land is regenerated by flowing groundwater, heat from the inside of the earth and heat coming from above. According to the principle of operation, heat pumps can also be known as compression-resorption heat pumps, vapour compression heat pumps and trans-critical heat pumps [6].

\section{Heat recovery using heat exchanger}

A heat exchanger is a device designed to transfer heat energy between two (or more) media being in a liquid or gaseous state of aggregation with different temperatures. According to the operational mode of the medium inside the heat exchanger, they can be classified as recuperative heat exchangers and regenerative heat exchangers. Besides, the recuperative heat exchangers include dividing-wall heat exchangers or hybrid heat 
exchangers. The characteristic of dividing-wall heat exchangers is that a solid wall separates hot fluid and cold fluid without mixing, and this is the most commonly used heat exchanger in practical applications [3]. The heat exchanger is an essential piece of equipment if analysing any heat recovery systems. To recover low-temperature waste heat, recuperative heat exchangers showed their advantages in heat exchange efficiency. In experimental conditions [7], the heat exchange efficiency reached $83.56 \%$ by combining a plate heat exchanger with a thermoelectric generator.

\section{Heat recovery using heat pipe}

The heat energy in waste air is valuable. With a heat pipe, you can recover most of it for free. The heat pipe extracts heat from the waste air stream and adds it to the incoming stream; it is a useful heat transfer device with simple configuration, fine compactness and without power requirements or movable mechanical parts [3]. When two air streams pass through the heat pipes, one airstream on the supply side and the other on the exhaust side, the temperature difference between the two air streams heats and cools refrigerant. The phase of the refrigerant changes, from a liquid to a vapour and back again, transferring energy from one side to the other [8]. Apart from the evaporator and the condenser, an adiabatic zone is a necessary part of the heat pipe system. It maintains a temperature difference between the evaporator end and the condenser end [3]. The performance of heat pipes mainly depends on the heat transfer rate of the heat pipe, which can be improved by increasing the diameter of the heat pipe and arranging heat pipes inline [9]. Around $20 \%$ of fuel consumption will be conserved in the furnace by using the full advantages of heat pipes [10].

\section{Power cycles (ORC, KCS, TLC)}

Nowadays, recovering waste heat for power generation is feasible and can be useful for directly, on-site applications in production facilities or transferred to residential consumers. Many studies focusing on waste heat-based power generation have been carried out in different regions all over the world [11-13]. The potential power cycles using low-temperature engines for converting the low-temperature waste heat into electricity mainly include (as shown in Fig. 1): Organic Rankine cycle (ORC), Kalina cycle (KCS) and Trilateral cycle (TLC) [3]. Organic Rankine cycle is a good solution within the utilization of waste heat due to its simplicity, flexibility, feasibility and relatively low driving temperature [14]. Organic Rankine cycle has simple start-up procedures, quiet operation, and excellent part-load performance [15]. The basic ORC cycle is built from an evaporator/heat recovery boiler, a turbine, a condenser and a working fluid pump. The working fluid absorbs the waste heat by heat change in the evaporator. The performance of ORC mainly depends on the operating working fluid [16]. Chosen fluids should face safety criteria, also be environmentally friendly and has a low-cost impact on the power plant [17]. For the Kalina cycle, the working fluid is an ammonia-water mixture; the main advantage of it is to have different boiling and condensing temperatures, resulting in lower exergy destruction. The TLC cycle consists of a pump, a heater, a two-phase expander and a condenser. Compared to the other two cycles, the characteristic of TLC cycle is that it is capable of matching the expected temperature profile on the source and sinking sides of the cycle [3]. 
a)

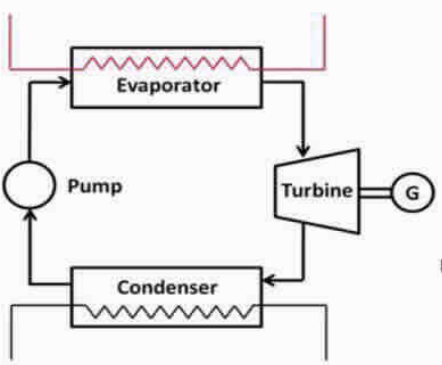

b)

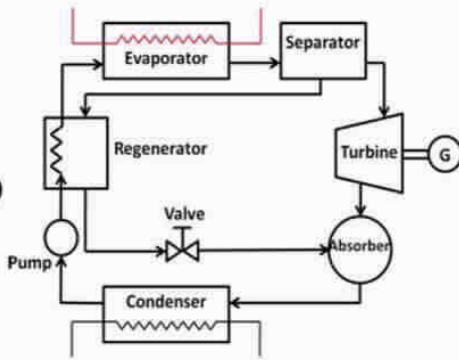

c)

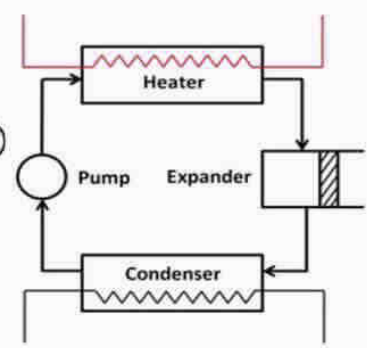

Fig. 1. Schematic diagrams of basic power cycles. From left side: a) ORC, b) KCS, c) TLC [3]

\section{Thermal energy storage}

The biggest issue, we have to face, is to utilize recovered heat during the whole year. The heat recovery systems are the most efficient when we can provide continuously heat collection from the waste heat source. The solution is to store waste heat and use later on when it is needed. The most problematic time for storing waste heat is summer season when there is too much of waste heat so we are not able to utilize it in $100 \%$. That is way there must be more studies in this field to provide cheap and efficient thermal energy storage.

Thermal energy storage (TES) is a way to stock thermal energy by heating or cooling medium which is stored. The stored energy can be utilize later on, whenever there is a mismatch between energy generation and use. Some essential factors have to be taken into account when talking about the type and the design of any thermal storage system, also a key issue is its thermal capacity [18]. TES systems are used particularly in buildings and in industrial processes. There are three types of TES systems according to different physics phenomena. Each of TES system is characterized by different capacity, efficiency, storage period and cost of investment. Energy storage systems can be described using above mentioned characteristics as followings:

1. Capacity is defined by the energy which is stored in the system and depends on the storage process, the medium, and the size of the system;

2. Power is defined by the speed of the energy stored in the system which is discharged (and charged);

3. Efficiency is the ratio of the energy provided to the user to the energy needed to charge the storage system;

4. Storage period is defined by time that the energy is stored and mainly lasts from hours to months;

5. Charge and discharge time is defined by the time that is needed to charge/discharge the system;

6. Cost refers to either capacity ( $€ / \mathrm{kWh})$ or power $(€ / \mathrm{kW})$ of the TES and depends on the capital and operation costs of the storage equipment and its lifetime [19].

Typical parameters of TES systems are listed in Table 1.

The most direct way is the storage of sensible heat. Sensible heat storage (SHS) is based on raising the temperature of a liquid or solid to store heat and releasing it with the decrease of temperature when it is required. The volumes needed to store energy in the 
scale that world needs are extremely large. Materials used in sensible heat storage must have high heat capacity and also high boiling or melting point. Although this method of heat storage is currently less efficient for heat storage, it is least complicated compared with latent or chemical heat and it is inexpensive. Table 2 shows the most used SHS materials and their properties [20]. Water appears to be the best SHS liquid available because it is inexpensive and has a high specific heat.

Table 1

Parameters of different TES systems [21]

\begin{tabular}{|c|c|c|c|c|c|}
\hline TES system & $\begin{array}{c}\text { Capacity } \\
{[\mathbf{k W h} / \mathbf{M g}]}\end{array}$ & $\begin{array}{c}\text { Power } \\
{[\mathbf{M W}]}\end{array}$ & $\begin{array}{c}\text { Efficiency } \\
{[\%]}\end{array}$ & $\begin{array}{c}\text { Storage } \\
\text { period }\end{array}$ & $\begin{array}{c}\text { Cost } \\
{[\mathbf{6} / \mathbf{k W h}]}\end{array}$ \\
\hline $\begin{array}{c}\text { Sensible } \\
\text { (hot water) }\end{array}$ & $10-50$ & $0.001-10$ & $50-90$ & days/months & $0.1-10$ \\
\hline $\begin{array}{c}\text { Phase-change } \\
\text { material } \\
\text { (PCM) }\end{array}$ & $50-150$ & $0.001-1$ & $75-90$ & hours/months & $10-50$ \\
\hline Chemical & $120-150$ & $0.01-1$ & $75-100$ & hours/days & $8-100$ \\
\hline
\end{tabular}

Table 2

Selected solid-liquid materials for sensible heat storage

\begin{tabular}{|c|c|c|c|c|}
\hline Medium & Fluid type & $\begin{array}{c}\text { Temperature } \\
\text { range }\left[{ }^{\circ} \mathbf{C}\right]\end{array}$ & $\begin{array}{c}\text { Density } \\
{\left[\mathbf{k g} / \mathbf{m}^{\mathbf{3}}\right]}\end{array}$ & $\begin{array}{c}\text { Specific heat } \\
{[\mathbf{J} /(\mathbf{k g} \cdot \mathbf{K})]}\end{array}$ \\
\hline Sand & - & 20 & 1,555 & 800 \\
\hline Rock & - & 20 & 2,560 & 879 \\
\hline Brick & - & 20 & 1,600 & 840 \\
\hline Aluminium & - & 20 & 2,707 & 896 \\
\hline Water & - & $0-100$ & 1,000 & 4,190 \\
\hline Engine oil & Oil & $\leq 160$ & 888 & 1,880 \\
\hline Ethanol & Organic liquid & $\leq 78$ & 790 & 2,400 \\
\hline Propane & Organic liquid & $\leq 97$ & 800 & 2,500 \\
\hline Butane & Organic liquid & $\leq 118$ & 809 & 2,400 \\
\hline
\end{tabular}

\section{Heat recovery potential in Bulten Poland S.A.}

Bulten Poland S.A. is a producer of specialized fasteners for automotive industry which demand many complicated operations during its technological process, for example, heat treatment which is an energy-consuming process and gives much potential within heat recovery. For this reason, Bulten Poland S.A. decided to conduct an industrial energy audit to evaluate heat recovery potential in the plant.

The analyses show that the most cost-effective undertaking reducing the costs of energy supply is to reuse waste heat.

Heat recovery systems will reduce the consumption of district heating and heat obtained from natural gas combustion (technological washers, hot water for social needs). All projects related to heat recovery are characterized by a fast payback time (SPBT $<2$ years). The largest and at the same time, the easiest to use waste heat source is the compressor cooling system. Also, there is a favourable circumstance a short distance from the compressor's heat distribution room - that is why the project is recommended for the fastest possible implementation. In the next step, the remaining plans for heat recovery are also recommended for implementation. The final result of these undertakings will be 
total resignation from the network heat supply and improvement of the efficiency of heat supply regulation, increase control over heat loads, the introduction of control automation (SyNiS supervision system).

Total resignation from the network heat supply and the construction of the auxiliary gas boiler room is also a cost-effective solution, but it requires significantly higher investment expenditures. This project may be implemented in conjunction with the implementation of heat recovery installations (from compressors, flue gases and a quenching bath). The arrangement of recovery installations (supported by gas boilers) will require appropriate solutions design (in the field of hydraulics and automation) ensuring the priority of using heat from recovery and switching on gas boilers only in conditions of shortage warm.

The primary and priority source of heat recovery installations:

1. Heat recovery from compressor cooling (oil/water heat exchanger)

2. Heat recovery from the exhaust stream of Aichelins' quenching furnace

3. Heat recovery from the exhaust stream of Dowas' quenching furnace

4. Heat recovery from the Aichelins' oil quenching bath (oil/water heat exchanger)

The maximum potential of recovered heat:

- from the air compressors $6,112 \mathrm{GJ} /$ year

- from the Aichelins' exhaust stream 4,365 GJ/year

- $\quad$ from the Dowas' exhaust stream 4,134 GJ/year

- from the oil baths' heat exchanger 4,455 GJ/year

Total: $18,965 \mathrm{GJ} /$ year

The maximum heat recovery potential is expressed by the amount of heat that is capable of recovering when heat sources work with nominal power throughout the year.

\section{Energy management modernizations at the industrial plant on the example of Bulten Poland S.A.}

\section{Heat recovery from air compressors}

There is a great potential in compressed air systems within recovering waste heat. Studies show that only, by lowering the discharge temperature to $373 \mathrm{~K}$ we are capable to reuse waste heat in amount of $32 \mathrm{~kW}$ per day [22].

For the heat recovery from the hot compressor cooling oil, an external "Duotherm" heat recovery system provided by the BOGE compressor manufacturer is to be installed. The system is based on a plate heat exchanger to which the oil circuit from the compressor is connected and the water circuit from the recovery installation. The amount of heat received in the heat exchanger is controlled by an integrated three-way valve with a thermostatic actuator. The flow of water in the compressor circuits will be forced by the operation of a variable-speed rotary pump controlled by an analogue signal to maintain the constant water temperature measured behind the heat exchanger. The flow of heated water is directed towards the heat buffer, which simultaneously functions as a hydraulic clutch. To measure the amount of heat generated, it is planned to install the LC1 heat meter [23]. 


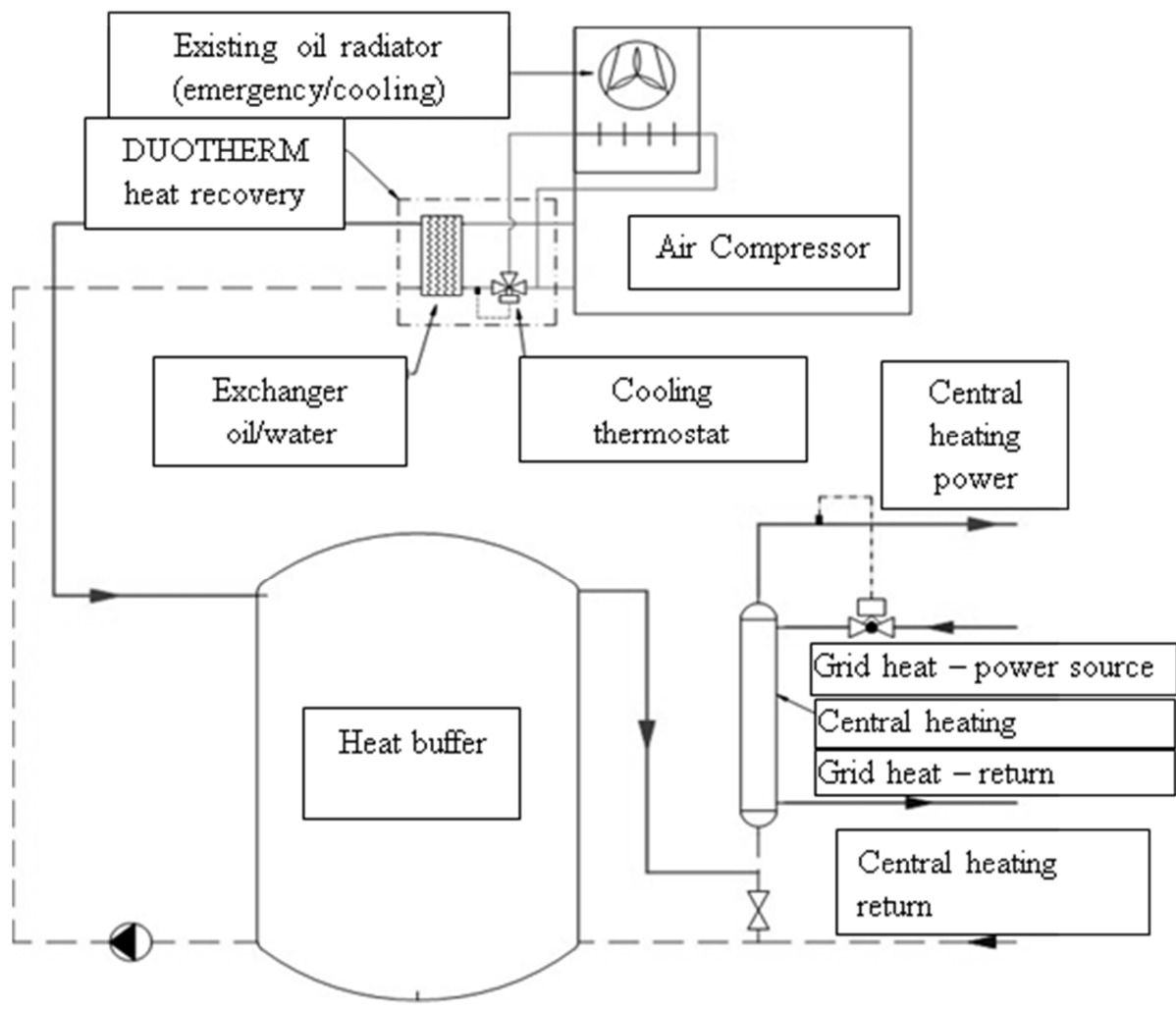

Fig. 2. Scheme of heat recovery from compressors

\section{Heat recovery from exhaust (Dowa and Aichelin)}

The exhaust gas economizer in the bypass of the main exhaust pipes. Behind the economizer will be installed exhaust gas fan with adjustable capacity. The system will be able to return to the existing state by opening the appropriate throttle and thrust breakers. Automation should protect the installation from overheating (expected during the summer season) by automatically opening the cold air intake to the economizer. PLC controller will do fan control (switching, modulation, shutdown) and throttle opening.

\section{Heat recovery from oil bath (Aichelin)}

The oil circuit between oil bath and oil cooler is characterized by high temperature $\left(75^{\circ} \mathrm{C}\right)$ and high flow (> $\left.100 \mathrm{Mg} / \mathrm{h}\right)$. To recover heat from the circulating oil, an additional exchanger is proposed as a first oil cooling rank. The heat exchanger must be connected in series to the oil circuit in front of the existing exchanger. The existing pump will force the oil flow, so the additional exchanger has to characterized by sufficiently low flow resistance on the oil side to keep the flow at a similar level as the existing one. The new system will be able to quickly return to the state before the modernization by opening/closing the proper shut-off valves (bypassing the new exchanger). The temperature sensor of the oil flowing into the exchanger will protect the oil against excessive cooling in 
the circuit. If the oil temperature falls below the setpoint, the valve will be closed on the waterside - the heat transferred to the heat buffer will be blocked. During operation there is no danger of water overheating in the circuit as the existing cooler controls the oil temperature, the electro valve opens the cooling water supply to the cooler when the oil temperature exceeds $77^{\circ} \mathrm{C}$.

\section{Lightening modernization}

The lighting system of the production halls is equipped with high-pressure lamps $400 \mathrm{~W}$ (Hi-Bay HID 400). The technical condition of these luminaires is good, however luminous flux (with the average consumption of light sources and contamination of optical system components luminaires) does not guarantee compliance with the required illuminance in workplaces. Due to the nature of production, lighting is used 24 hours a day on the plant's working days. The modernization includes replacement of lighting luminaires into MCNext HB-100-B1 $100 \mathrm{~W}$.

The planned lighting system is characterized by lower energy consumption compared to the method used so far. This is due, inter alia, to the following factors: higher efficiency of the luminaire (light sources are integrated with the luminaire and given in light stream catalogue, and luminous efficacy apply to the entire luminaire), a smaller drop luminous flux due to the usage of light sources, improved uniformity of light (level illuminance between luminaires).

Table 3

Before modernization

\begin{tabular}{|c|c|c|c|}
\hline Type/ Place & $\begin{array}{c}\text { Quantity } \\
{[\mathbf{p s c}]}\end{array}$ & $\begin{array}{c}\text { Unit power } \\
{[\mathbf{W}]}\end{array}$ & $\begin{array}{c}\text { Total power } \\
{[\mathbf{k W}]}\end{array}$ \\
\hline Hi Bay HID 400/ H3 hall & 12 & 440 & 5,280 \\
\hline Hi Bay HID 400/ H4 hall & 8 & 440 & 3,520 \\
\hline Hi Bay HID 400/ H1 and H7 hall & 80 & 440 & 35,200 \\
\hline Total & - & - & 44,000 \\
\hline
\end{tabular}

Table 4

After modernization

\begin{tabular}{|c|c|c|c|}
\hline Type/ Place & $\begin{array}{c}\text { Quantity } \\
{[\mathbf{p s c}]}\end{array}$ & $\begin{array}{c}\text { Unit power } \\
{[\mathbf{W}]}\end{array}$ & $\begin{array}{c}\text { Total power } \\
{[\mathbf{k W}]}\end{array}$ \\
\hline MCNext HB-100-B1 400/ H3 hall & 12 & 100 & 1,200 \\
\hline MCNext HB-100-B1 400/ H4 hall & 8 & 100 & 800 \\
\hline $\begin{array}{c}\text { MCNext HB-100-B1 400/ H1 and } \\
\text { H7 hall }\end{array}$ & 80 & 100 & 8,000 \\
\hline Total & - & - & 10,000 \\
\hline
\end{tabular}

Table 5

Energy, economic and ecological effects of the modernization

\begin{tabular}{|c|c|c|c|}
\hline Factor & $\begin{array}{c}\text { Before } \\
\text { modernization }\end{array}$ & $\begin{array}{c}\text { After } \\
\text { modernization }\end{array}$ & Savings \\
\hline Final energy [kWh/year] & 321,024 & 72,960 & 248,064 \\
\hline Primary energy [kWh/year] & 963,072 & 218,880 & 744,192 \\
\hline $\mathrm{CO}_{2}$ emission [Mg/year] & 266.9 & 60.7 & 206.3 \\
\hline Costs [PLN] & 95,813 & 21,776 & 74,037 \\
\hline
\end{tabular}


Calculations of final/primary energy savings were calculated as the difference in final/primary energy consumption before implementation venture (Table 3 ) to its use after the implementation (Table 4) of the project to improve energy efficiency in the plant.

List of calculated energy, economic and ecological effects are presented in the Table 5.

\section{Cogeneration}

Cogeneration helps effectively use the primary energy contained in the fuel. It is usually carried out in piston combustion engines or gas flow engines: so-called gas turbines. The main, useful form of energy produced in cogeneration is electricity. This production is accompanied by the release of heat, which can be effectively managed. Therefore, considering the use of a cogenerator should focus mainly on making the most of the heat that is used in the cogeneration process is a significant part of the primary energy input. This heat, in the form of hot water (up to $90{ }^{\circ} \mathrm{C}$ ), can be used for heating purposes (technological or heating of buildings), preparation of heat treatment or power absorption chiller (in the so-called trigeneration processes). Wherever there is a demand for energy, electricity, heat and cold, it is possible to install a cogeneration system integrated with a refrigeration appliance. There are two types of refrigerators absorbers: Bromolytic $\left(\mathrm{LiBr} / \mathrm{H}_{2} \mathrm{O}\right)$ and ammonia $\left(\mathrm{H}_{2} \mathrm{O} / \mathrm{NH}_{3}\right)$. Application of the first one is limited to manufacturing refrigerant with temperature for a minimum level of about $5{ }^{\circ} \mathrm{C}$. Typically, they find use in air conditioning systems. Ammonia absorbers are applicable mainly in industrial operations where the required temperature of the refrigerant being produced is below $0{ }^{\circ} \mathrm{C}$. When using ammonia, it is possible for deep freezing up to $60{ }^{\circ} \mathrm{C}$ [24].

Absorbers give the possibility of effective use of waste heat from the electricity generation process (during the heating season for the production of heat and in the summer season for air conditioning purposes). Production of cold in the summer season extends the annual use of the engine and turbine, and thus increases the annual production of electricity [24].

The efficiency of gas cogeneration reaches $75 \%$ to over $90 \%$ (for heat production) when electrical efficiency reaches $30-40 \%$ for piston engines and between $25-35 \%$ for gas turbines [25].

To ensure a high degree of heat utilisation from the cogenerator, it's thermal power must be selected in the way the unit will perform as many hours as possible, having a constant heat reception on user needs. It is also necessary for applying for energy certificates of so-called yellow certificates - they are issued for electricity generated in high-efficiency (> $75 \%$ ) cogeneration.

The profitability analysis for this type of investment in Bulten Poland S.A. must be carried out to determine the economic aspects of this undertaking.

\section{Conclusion}

Bearing in mind the continuous global increase in the energy intensity of the industrial sector, we should continuously look for ways to improve the energy efficiency of production plants. The essential step in these activities is to carry out an industrial energy audit, the result of which is potentially the most beneficial activities to improve the energy efficiency of the plant under investigation. In the Bulten Poland S.A. after the audit and economic analysis, those with the fastest simple payback time were selected, and their implementation started. 
Based on the situation at the Bulten Poland S.A. production plant the most beneficial investment aimed at improving energy efficiency was combined heat recovery system which helps utilize waste heat from compressors, exhaust gases and oil bath of the hardening furnace. This solution made Bulten Poland S.A. independent within heat supplies from the city.

All applied solutions in the Bulten Poland S.A. can be successfully implemented in any industrial plant that produces fasteners or uses compressed air for their purposes and has high temperature processes.

Furthermore, it is recommended to conduct a full economic analysis for the use of cogeneration combined with the recovery of heat generated during the electricity production and the possibility of using simultaneously the absorber system to produce coldness in the summer season. However, the uncertainty of this investment is quite large, because of the lack of continuously needs for coldness and high costs of the absorption chiller.

\section{Acknowledgments}

This work was prepared within the implementation doctorates scholarship thanks to the Polish Ministry of Science and Higher Education.

\section{References}

[1] The official portal of the European Union. https://europa.eu/european-union/topics/energy_en [online access 24.09.2018].

[2] Website of the European Parliament. https://www.europarl.europa.eu/factsheets/en/sheet/68/ energy-policy-general-principles [online access 24.09.2018].

[3] Baleynaud JM, Huang F, Zheng J, Baleynaud JM, Lu J. Heat recovery potentials and technologies in industrial zones. J Energy Inst. 2016;90:951-61. DOI: 10.1016/j.joei.2016.07.012.

[4] Gielen D, Bennaceur K, Kerr T, Tam C, Tanaka K, Taylor M, et al. IEA, Tracking Industrial Energy Efficiency and $\mathrm{CO}_{2}$ Emissions. https://www.researchgate.net/publication/ 279804486_IEA_Tracking_Industrial_Energy_Efficiency_and_CO2_Emissions [online access 24.09.2018].

[5] Independent Statistics \& Analysis. U.S. Energy Information Administration. 2017. https://www.eia.gov/todayinenergy/detail.php?id=32912 [online access 24.09.2018]

[6] Van de Bor D, Ferreira CI, Kiss AA. Low grade waste heat recovery using heat pumps and power cycles. Energy. 2015;89:864-73. DOI: 10.1016/j.energy.2015.06.030.

[7] Wang T, Luan W, Wang W, Tu ST. Waste heat recovery through plate heat exchanger based thermoelectric generator system. Appl Energy. 2014;136:860-5. DOI: 10.1016/j.apenergy.2014.07.083

[8] Energy Recovery Heat Pipes. 5 Advantages of using Heat Pipes for Air-To-Air Energy Recovery. http://www.dac-hvac.com/energy-recovery-heat-pipes-5-advantages-of-using-heat-pipes-for-air-to-airenergy-recovery/ [online access 24.09.2018].

[9] Yodrak L, Rittidech S, Poomsa N, Meena P. Waste heat recovery by heat pipe air-preheater to energy thrift from the furnace in a hot forging process. Am J Appl Sci. 2010;7:675-81. DOI: 10.3844/ajassp.2010.675.681.

[10] Shabgard H, Allen MJ, Sharifi N, Benn SP, Faghri A, Bergman TL. Heat pipe heat exchangers and heat sinks: opportunities, challenges, applications, analysis, and state of the art. Int J Heat Mass Transfer. 2015;89:138-58. DOI: 10.1016/j.ijheatmasstransfer.2015.05.020.

[11] Thu K, Yanagi H, Saha BB, Ng KC. Performance analysis of a low-temperature waste heat-driven adsorption desalination prototype. Int $\mathrm{J}$ Heat Mass Transfer. 2013;65:662-9. DOI: 10.1016/j.ijheatmasstransfer.2013.06.053.

[12] Peris B, Navarro-Esbrí J, Moles F, Mota-Babiloni A. Experimental study of an ORC (organic Rankine cycle) for low grade waste heat recovery in a ceramic industry. Energy. 2015;85:534-42. DOI: 10.1016/j.energy.2015.03.065. 
[13] Khatita MA, Tamer SA, Ashour FH, Ismail I. Power generation using waste heat recovery by organic Rankine cycle in oil and gas sector in Egypt: a case study. Energy. 2014;64:462-72. DOI: 10.1016/j.energy.2013.11.011.

[14] Gao P, Jiang L, Wang LW, Wang RZ, Song FP. Simulation and experiments on an ORC system with different scroll expanders based on energy and exergy analysis. Appl Therm Eng. 2015;75:880-8. DOI: 10.1016/j.applthermaleng.2014.10.044.

[15] Stijepovic MZ, Papadopoulos AI, Linke P, Grujic AS, Seferlis P. An exergy composite curves approach for the design of optimum multi-pressure organic Rankine cycle processes. Energy. 2014;69:285-98. DOI: 10.1016/ j.energy.2014.03.006.

[16] Stijepovic M, Linke P, Papadopoulos A, Grujic A. On the role of working fluid properties in Organic Rankine Cycle performance. Appl Therm Eng. 2012;36:406-13. DOI: 10.1016/j.applthermaleng.2011.10.057.

[17] Saleh B, Koglbauer G, Wendland M, Fischer J. Working fluids for low-temperature organic Rankine cycles. Energy. 2007;32:1210-21. DOI: 10.1016/j.energy.2006.07.001.

[18] Cabeza LF, Oró E. Thermal energy storage for renewable heating and cooling systems. Renew Heating Cooling. Technologies Applications. 2016:139-79. DOI: 10.1016/B978-1-78242-213-6.00007-2

[19] Chowdhury Y, Chowdhury H, Barua P, Salam B. Waste Heat Thermal Storage. A Way to Renewable Energy. Int Conf Mechanical, Industrial Materials Eng. 2017 (ICMIME2017). Rajshahi University of Engineering \& Technology. https://www.researchgate.net/publication/325415854_Waste_Heat_Thermal_ Storage_A_Way_to_Renewable_Energy [online access 24.09.2018].

[20] Sarbu I, Sebarchievici CA. Comprehensive review of thermal energy storage. Sustainability. 2018;10:191-223. DOI: 10.3390/su10010191.

[21] Ayappan S, Mayilsamy K, Sreenarayanan VV. Performance improvement studies in a solar greenhouse drier using sensible heat storage materials. Heat Mass Transfer. 2016;52:459-66. DOI: 10.1007/s00231-015-1568-5.

[22] Mascarenhas JS, Chowdhury H, Thirugnanasambandam M, Chowdhury T, Saidur R. Energy, exergy, sustainability, and emission analysis of industrial air compressors. J Cleaner Prod. 2019;231:183-95. DOI: 10.1016/j.jclepro.2019.05.158.

[23] Broniszewski M, Werle S. The study on the heat recovery from air compressors. 17th Int Conf Heat Transfer Renew Sources Energy (HTRSE-2018). E3S Web of Conferences. DOI: 10.1051/e3sconf/20187003001.

[24] Raj TN, Iniyan S, Goic R. A review of renewable energy based cogeneration technologies. Renew Sust Energy Rev. 2011;15:3640-8. DOI: 10.1016/j.rser.2011.06.003.

[25] Broniszewski $\mathrm{M}$, Werle $\mathrm{S}$. $\mathrm{CO}_{2}$ reduction methods and evaluation of proposed energy efficiency improvements in Poland's large industrial plant. Energy. 2020. DOI: 10.1016/j.energy.2020.117704. 